\title{
THE LYRICAL NOVEL LORD OF THE FLIES
}

\author{
A NARRATIVA POÉTICA O SENHOR DAS MOSCAS
}

\author{
Natasha Costa \\ UNESP - Araraquara
}

\begin{abstract}
The academic researches on the narrative Lord of the Flies, published in 1954 by William Golding, classify it explicit or implicitly as a traditional novel. In this article we intend to show that this work, instead of narrating an individual human experience based on social or cultural terms, focus a mythological and less diffuse subjective experience by using the resources of poetry. In order to study the poetic narrative, or lyrical novel, this research will be founded on the considerations of Jean-Yves Tadié (1978) exposed in Le récit poétique and those of Ralph Freedman (1963) in The lyrical novel. This paper attempts to show that mainly space, time, myth and allegory imprints a poetic form in the essence of the narrative.
\end{abstract}

KEYWORDS: Lyrical novel; Space; Time; Myth; Allegory.

RESUMO: As pesquisas acadêmicas sobre a narrativa $O$ senhor das moscas, publicada em 1954 por William Golding, classificam-na explícita ou implicitamente de romance tradicional. Neste artigo pretendemos mostrar que a referida obra, em vez de narrar uma experiência humana individual pautada em uma relação social ou cultural, volta-se para uma experiência subjetiva mitológica e menos difusa recorrendo aos recursos da poesia. Para o estudo da narrativa poética, ou romance lírico, esta pesquisa será fundamentada nas considerações de Jean-Yves Tadié (1978) em Le récit poétique e de Ralph Freedman (1963) em The lyrical novel. Buscar-se-á mostrar que, principalmente, o espaço, o tempo, o mito e a alegoria imprimem uma forma poética à essência da narrativa.

PALAVRAS-CHAVE: Narrativa poética; Espaço; Tempo; Mito; Alegoria.

\section{INTRODUCTION}

The foretelling title of the narrative Lord of the flies translates literally the Hebrew term Beelzebub, one of the seven demons of Hell. Thus one probably will not expect to be facing a conventional children's story of adventures which highlights the innocence, naughtiness, and creativity inherent in childhood.

William Golding could have narrated a particular happening by making heavy use of specific cultural or social circumstances, but the author chose to focus on the subjective, human experience mainly through the poetic outlining of the categories of space, time, allegory and the unlimited and atemporal aspect of myth. Therefore, this paper intends to 


\section{Revista do SELL}

v. $4, n^{\circ} .2$

ISSN: $1983-3873$

show that Lord of the flies can be defined as the hybrid genre of poetic narrative, as terms Jean-Yves Tadié in Le récit poétique (1978), or lyrical novel, as labels Ralph Freedman in The lyrical novel (1963).

As Freedman explains, the lyrical fiction is an anti-novel due to its attempt to reconcile temporal sequences of cause and effect with the immediate action of the lyric and, in this sense, time is experienced spatially. In subverting the accepted qualities of the novel, this paradoxical submersion in imagery portrays directly the act of knowledge, of awareness, which could be symbolized by Ralph's perception of the loss of innocence at the end of the narrative.

The French author Jean-Yves Tadié approaches similarly this modern genre by describing its compositional essence as a transitional phenomenon between poetry and novel. This way the poetic narrative encompasses a system of echoes, reprises and contrasts which resembles assonances, alliterations and rhymes. Tadié also draws attention to the constant conflict in this double-faceted configuration between the referential purpose of literature, related to evocation and representation, and its poetic function, which accentuates the form of the message.

In analyzing the synergic interweaving of childhood with profound and grim themes such as death, pride and instinct as well as the composition of space, time, myth and allegory as the categories responsible for accentuating the poetry essential to the lyrical novel, our intention is to show how such thematic possibilities and its formal realization echo the genre of poetic narrative and diverge ultimately from the qualities of a standard novel based on the observations made by the cited literary theorists.

The author of Lord of the flies, Sir William Gerald Golding, was born in England in 1911 and won the Nobel Prize in Literature in 1983. His having joined the Royal Navy in the Second World War was an experience which deeply affected the way he saw humanity and our capability for evil. The author distinctively states about this 1954 work:

Before the Second World War I believed in the perfectibility of social man; that a correct structure of society would produce goodwill; and that therefore you could remove all social ills by a reorganization of society. It is possible that today I believe something of the same again; but after the war I did not because I was unable to. I had discovered what one man could do to another. I am not talking of one man killing another with a gun, or dropping a bomb on him or blowing him up or torpedoing him. I am thinking of the vileness beyond all words that went on, year after year, in the totalitarian states. (GOLDING, 1965, p. 85). 


\section{Revista do SELL}

v. $4, \mathrm{n}^{\circ} .2$

ISSN: $1983-3873$

In his attempt to outline the defects of society back to the faults of human nature, Golding excluded from this lyrical fiction external propelling circumstances which could arguably be credited with a violent, domineering impetus such as the adult solidified world of hierarchic statuses and wide-ranging factors such as famine, imminent danger and the need to work, allowing the marooned schoolboys to cultivate chiefly the traits inherent in human character.

However, at the same time Golding omits such factors, he depicts a group of British boys who will inevitably impersonate the adult society: they organize themselves in smaller assemblages to hunt, to build shelters for safety and to investigate the imminent threat of the beast. This deliberate resemblance emphasizes the author's philosophical enterprise: to show the immutable core of human soul and perhaps incite our advancement in both individual and social spheres.

\section{Space}

In distinguishing the differences between the traditional and the lyrical novel, for instance, Freedman (1963, p. 8) underlines that an influential and decisive element is the locus of this fictional world. In conventional narratives, the external world is the thing. It is beyond writer and reader, "interposing between them and the theme". In lyrical novels, the locus is conceived not as a universe where men display their actions, "but as a poet's vision fashioned as a design."

In Lord, Golding conceives the idea of locus by electing the paradisiac place of a reassuring island abundant with fruits and an Eden-like scenery:

Beyond the platform there was more enchantment. Some act of God - a typhoon perhaps, or the storm that had accompanied his own arrival - had banked sand inside the lagoon so that there was a long, deep pool in the beach with a high ledge of pink granite at the further end. Ralph had been deceived before now by the specious appearance of depth in a beach pool and he approached this one preparing to be disappointed. But the island ran true to form and the incredible pool, which clearly was only invaded by the sea at high tide, was so deep at one end as to be dark green. (GOLDING, 1988, p. 10-11).

The primary role of this peaceful and newly-discovered place is to harmonize with the feelings of the boys, who are initially content with such a heavenly fortune of being free from adult restraints in a deserted island. In the same sense the island is sheer nature or at most a potential commencement of civilization, the group of kids also demonstrates their 


\section{Revista do SELL}

v. $4, n^{\circ} .2$

ISSN: $1983-3873$

raw innate quality. Besides homologating their state of mind and egotistical essence, the literary space will at the same time influence the boys' deeds and set them in motion, allowing for the evident fact none of those tragedies would have happened were they at some cultured place.

It is possible to notice that these early spatial aspects of tranquility, wonderland and harmony are inescapably connected to the form of its description. In the excerpt above, for instance, the repetition of the phoneme /s/ in "some", "storm", "sand", "deceived", "specious", "appearance", "disappointed", etc. may echo the idea of whisper and murmur, while the reiteration of /t/ in "platform", "enchantment", "act", "typhoon", "storm", "granite", "tide", etc. evokes a shock, a clatter. We would not be mistaken in assuming that such phonemic quality possibly mimes the undulating movement of the water involved in the scene. This inseparable bond between sounds and meanings is poetic in nature.

As the narrative progresses and we see the formation of a dialectic social structure instigated by Ralph and Jack's dispute, the space also sustains such collision by making possible the coexistence of two areas pertaining to each of the leaders, who symbolize the poles of civilization ("rules are the only thing we've got!") and instinct ("the compulsion to track down and kill"). This conflict is clearly established in the narrative when Jack, in chapter 8, runs along the beach crying after a poll to choose the chief. Later, Jack founds his own group: "Far off along the beach, Jack was standing before a small group of boys. He was looking brilliantly happy." (GOLDING, 1988, p. 136).

Tadie (1978) defines literary space as the accumulation of signs which produce an effect of representation. The author also argues that the image cannot be isolated from its context, be it the whole of a description - supposing we could isolate it - be it the whole of a narrative. Tadié explains that the organization of these spatial signs in the poetic narrative follows a binary rhythm based on the opposition between its beneficial and harmful features. This structure is well designed in Lord of the flies due to the alluded partition of the groups and the subsequent qualities the spaces acquire with their presence.

Besides, Tadie affirms that the description of the poetic space is open to symbols, to fascination, to echoes, and calls for a center, the navel of the world. This image reinforces the relevance of the island ("maison flottante sur la mer") and its self-contained system to this literary genre. Even when the poetic narrative illustrates certain images of voyage concerning the theme of the island, the author argues, it is common that the writer 


\section{Revista do SELL}

v. $4, n^{\circ} .2$

ISSN: $1983-3873$

explores the image of the shipwreck, ratifying our reading of the space in Lord. This type of fiction frequently elects a paradisiac place, in contrast with the sceneries of meeting in realist novels, whose authors expand the occasions of enclosure in the portrayal of markets, shops and farms.

Lord's edenic island, related to "some act of God", is one of the elements that make possible the understanding of this narrative, destitute of peripheral locations, as an allegory (a topic to be studied later). Behind the representation of an uninhabited coast and forest, lies an essay concerning the creation of man in a paradise, dating back to an immemorial, biblical time. The space of this poetic narrative radiates stratified time in its uncontaminated originality: "Only when Jack himself roused a gaudy bird from a primitive nest of sticks was the silence shattered and echoes set ringing by a harsh cry that seemed to come out of the abyss of ages." (GOLDING, 1988, p. 48).

Regarding this relation between spatial and temporal signs, Tadié elucidates that the creation of a place and the creation of a time constitute the same process and complements that:

Si, dans son mouvement, le récit poétique est celui d'une quête ; si son temps est immobile; sa structure, circulaire ou discontinue (et non pas celle, de cause à effet, d'une intrigue) ; son espace, valorisé, manichéen ; alors la lecture des symboles nous confirme que cette quête, ce temps, cet espace son ceux d'un paradis perdu. S'il a disparu, le récit suscite. ${ }^{1}$ (TADIÉ, 1978, p. 164-5).

When the writer reaches plenitude in finding his designated land, his templum, he associates it with a lost paradise by artistically elaborating the ideas of search, immovable time and bifurcate space. As we can see, the notions of discontinuity, immobility and circularity are coherently transfigured in the form of a deserted island: Lord of the flies resuscitates the unalterable malicious essence of men by means of a loop. In this sense, space and time are inextricably interrelated by these connotations of circle: "Pour peindre ce temps flottant, arrêté, l'écrivain retrouve naturellement l'image de l'île [...]"² (TADIÉ, 1978, p. 86).

\footnotetext{
${ }^{1}$ If, in its movement, the poetic narrative is that of a quest, if time is immobile and its structure circular or discontinuous (and not that of cause and effect pertaining to a plot); its space, valued, Manichaean, so the reading of symbols confirms that this quest, this time, this space are those of a lost paradise. If it is gone, the narrative evokes it. (TADIÉ, 1978, p. 164-5). (own translation).

${ }^{2}$ To paint this floating, fixed time, the writer naturally recovers the image of the island [...] (TADIÉ, 1978, p. 86). (own translation).
} 


\section{Revista do SELL}

v. $4, n^{\circ} .2$

ISSN: $1983-3873$

The final configuration of the narrative also confirms this circuitousness by reinserting the children in the grown-up world they have been allegorically representing. It is also worth noting the transfiguration that literary space undergoes throughout the narrative, a transition required to achieve the author's aesthetic design. Ralph Freedman (1963) explains that the lyric, as distinct from drama and epic, is regarded either as an immediate expression of a feeling or as a spatial form: the reader approaches the lyric the way an observer regards a picture. Concerning further peculiarities of the lyric, the author clarifies that:

Yet as a lyrical poem moves from image to image, it also follows its own inimitable progression, acting through variations and expansions of themes, changes in rhythm, and elaborations of images to reach a point of greatest intensity at which the poet's vision is realized. (FREEDMAN, 1963, p. 6-7).

Reflecting on Lord of the flies, it is possible to assume that the pictorial evolution to untidiness and chaos - which shocked the naval officer at the end - epitomizes metaphorically the gradual revelation of the human soul, apparently unable to sustain its compassionate and virtuous nature in a confined environment. A similar structure can be found in the novel Ensaio sobre a cegueira (1995), by the Portuguese writer José Saramago (1922-2010), and in the movie El ángel exterminador (1962) by the Spanish filmmaker Luis Buñuel (1900-1983).

\section{Time}

Regarding this important aspect of temporal marks in the lyrical novel, Tadié (1978, p. 85) explains that "Le récit poétique cherche à échapper au temps par la remontée jusqu'aux origines de la vie, de l'histoire et du monde: contrairemente à la science-fiction, l'avenir l'intéresse peu. D'où le grand nombre de ces textes consacrés à l'enfance [...]". ${ }^{3}$

Time in lyrical novels makes reference to the origins of life, of the world. In Lord of the flies time is connected to a scriptural holy place by means of an island touched by God and, throughout the narrative, the primitive aspect of this unpeopled land is ratified. Moreover, temporal indicators in poetic narratives rely on inner landscape rather than on

\footnotetext{
${ }^{3}$ The poetic narrative seeks to escape time by recovering the origins of life, history and the world: unlike science fiction, future attracts little interest. Hence the large number of texts concerning childhood [...] (TADIÉ, 1978, p. 85). (own translation).
} 


\section{Revista do SELL}

v. $4, n^{\circ} .2$

ISSN: $1983-3873$

conventional, realist passage of time based on date: it is more common to deal with moon phases, seasons and day/night dichotomy:

The first rhythm that they became used to was the slow swing from dawn to quick dusk. They accepted the pleasures of morning, the bright sun, the whelming sea and sweet air, as a time when play was good and life so full that hope was not necessary and therefore forgotten. Toward noon, as the floods of light fell more nearly to the perpendicular, the stark colors of the morning were smoothed in pearl and opalescence; and the heat - as though the impending sun's height gave it momentum - became a blow that they ducked, running to the shade and lying there, perhaps even sleeping. (GOLDING, 1988, p. 57).

Temporal issues are shaped in Lord mainly through the children's enjoyment of idleness as well as the exploring of the island and the building of huts in daylight. This portrayal of time harmonizes with the lyrical texts dedicated to childhood. Unconcerned with the individual past and future, "La chronologie, dans les récits enfantins, répond à la question: 'Quelle heure est-il?', et non à: 'Quel jour, quelle année sommes-nous?"4 (TADIÉ, 1978, p. 86).

However, one might justifiably argue that apprehensions about the future are indeed part of the plot: the making and maintenance of the bonfire, for instance, could be the element which represents their concern with the future, with the possibility of salvation. Therefore as the kids become more and more engulfed with their newly-adjusted and instinctive life, the fire becomes the symbol of a conceivable future rescue, granting the narrative a dramatic suspense.

Although this specific temporal denotation diverges slight from the aspects of the lyrical novel, it is worth remembering that many theorists, including Tzvetan Todorov in Genres in Discourse (1990), argue that one isolated literary device is not sufficient to determine or disclaim the poetic nature of a narrative. Rather, only the conjoined action of such proprieties will produce the poetic effect. Taking that into consideration, it is possible to see that this interpretation does not discredit at all the lyrical nature of Lord because it deals with the future to some extent.

\section{Myth}

\footnotetext{
${ }^{4}$ Chronology, in children's stories, answers the question "what time is it?" and not "what day, what year are we?" (TADIE, 1978, p. 86). (own translation).
} 


\section{Revista do SELL}

v. $4, n^{\circ} .2$

ISSN: $1983-3873$

Myth, in third place, is a strong indicator of the lyrical essence of the narrative. As a resource of literary representation, myth expresses an event which occurred for the first time and is indissolubly associated with portrayal of the human condition, Golding's primary purpose. In connecting with the universal through the illustration of the present time, the poetic narrative exposes how a given reality came into being.

In Lord of the flies, we are shown the early development of the human race, an idea suggested by the practice of ancestral ceremonies such as sacrificial offer and masking in "This head is for the beast. It's a gift." (GOLDING, 1988, p. 140) and:

He looked in astonishment, no longer at himself but at an awesome stranger. He spilt the water and leapt to his feet, laughing excitedly. Beside the pool his sinewy body held up a mask that drew their eyes and appalled them. He began to dance and his laughter became a bloodthirsty snarling. He capered toward Bill, and the mask was a thing on its own, behind which Jack hid, liberated from shame and self-consciousness. (GOLDING, 1988, p. 63).

We often read in Lord such primitive practices which lead the imagination of the reader back to immemorial and tribal eras, a movement articulated with the search for identity recurrent in lyrical novels. The narrative leaves behind the manufactured adult world of civilization and Golding bases its reconstruction only on the feeble remainders of society devised by the adolescent boys of the group, bringing forth the existential purpose inherent in this type of narrative.

While the realist novel focuses on actions arranged in determined space and time and competes with what happens in the world in the sense it creates an illusion of life, the lyrical novel intends to replace something in the world. Dissatisfied with his own posture towards the origins of evil, accredited to the structure of society, Golding recreates a mythological story that replaces this first idea by exposing, in his opinion, a more authentic view of the human disposition.

According to Tadié (1978), the poetic narrative is either composed entirely of myths; or incorporates them by means of embedded stories; or their presence is subterraneous and can only be identified because of some episodes or some heroes. The myth is a genuine history of origins for the members of a society where it still exists and allows the people to understand the horizon of things. In order to provide further definition of myth and its literary function, Tadié turns to the main ideas of the Romanian historian and philosopher Mircea Eliade: 


\section{Revista do SELL}

v. $4, n^{\circ} .2$

ISSN: $1983-3873$

[...] le mythe est une histoire sacrée, qui se déroule dans un temps primordial, avec des personnages donnés comme réels, mais surnaturels ; cette histoire raconte comment une réalité, totale ou partielle, est venue à l'existence; c'est donc toujours le récit d'une genèse qui montre par quelles voies l'irruption du sacré fonde le monde. La fonction du mythe est de 'révéler les modèles exemplaires de tous les rites et de toutes les activités humaines significatives'. ${ }^{5}$ (TADIE, 1978, p. 148).

By establishing the mythical background for his fiction with such ritualistic situations and embryonic time and space, Golding creates a veritable circumstance in which the boys expose their instinct and commit murder. Through the myth, the author associates deliberately the true primitive nature of men with the act of blind violence.

The mythical hero in the lyrical novel is indefinable: he exists only to experience something. Considering this type of narrative deals with the immediate instant, little information is given about Ralph's past, for instance. He and the others are designed for their sole purpose of fulfilling their exemplary roles in exposing the soul of men through a legendary narrative.

Concerning the mythological figures alluded to in Lord, it is defensible that the theft of Piggy's glasses for the making of fire by Jack's group resembles the story of Prometheus, one of the Titans who stole fire for humankind from Heaven as an incentive for their development. However, the violent, adverse and egotistical qualities of this act, which was also a source of work and war, are highly emphasized: this group will smoke Ralph out of his hiding-place with the purpose of killing him and their rescue will only bring to scene the same foreboding world they were representing.

Another important and eminent mythology is the story of Jesus Christ, whose spirituality strongly resembles Simon's. Etymologically, his name means "the one who hears/has heard the word of God" and this unworldliness is verified in his meeting with the beast, pointing to Christ's confrontation with the devil:

"Well then," said the Lord of the Flies, "you'd better run off and play with the others. They think you're batty. You don't want Ralph to think you're batty, do you? You like Ralph a lot, don't you? And Piggy, and Jack?"

Simon's head was tilted slightly up. His eyes could not break away and the Lord of the Flies hung in space before him. (GOLDING, 1988, p. 146).

\footnotetext{
${ }^{5}[\ldots]$ myth is a sacred story which takes place in a primeval time and whose characters are given as real, but supernatural; this story tells how a reality, total or partial, comes into existence; thus it is always the story of a genesis which shows the ways by which the irruption of the sacred founds the world. The purpose of myth is to "reveal exemplary models of all rites and of all significant human activities". (TADIE, 1978, p. 148). (own translation).
} 


\section{Revista do SELL}

v. $4, n^{\circ} .2$

ISSN: $1983-3873$

Whereas both characters are killed sacrificially and radiate moral truth and goodness, Simon's death does not promote salvation.

An interesting and equally possible perspective concerning these characters is conceived briefly by Arnold Kruger (2010, p. 61), to whom Simon's existence is analogous to that of the apostle Simon Peter: "The distinction between the roles of Christ and his apostle may seem a fine one, but the essential elements of the difference are important both to the story and its underlying allegory." The author goes on enumerating these common elements, such as the image of both characters placing ripe fruit into the hands of children, their weak countenance and Simon's final utterance about a dead man on a hill, imitating Peter's allusion to Christ.

These two standpoints seem equivalently persuasive regarding Lord of the flies and anyway validate the dichotomy between spiritualized or civilized and bestiality or barbaric, mirrored respectively in the characters of Simon, Ralph, the Beast and Jack. The elucidation produced by the confrontation between Simon and the Beast in a mythological time communicates an artistic configuration of man and evil to a post Second War society, indicating, with such retrogression and underlying criticism, the lack of spiritual development.

In studying awareness in Virginia Woolf's Between the acts, Ralph Freedman affirms that

The moment of illumination in life is juxtaposed with an archetypical image of time; the social world is transfixed by a mythical world through the intervention of art. Both levels are brought together by the performance of a play which acts simultaneously as the content of the novel and as a symbolic motif. (FREEDMAN, 1963, p. 269).

This could certainly be said of Lord, a book that represents in a creative and mythological way the illumination in the act of uncovering the malicious essence of men.

\section{Allegory}

The aforementioned meeting between Simon and the Beast is also related to the last topic we intend to discuss in this paper: allegory, a literary device which concerns the reading beyond the apparent plot. In order to fully comprehend the lyrical novel, composed intensely of allegory, the reader should seek for the primary motivation of the fiction, a more profound meaning. Lord of the flies, as a figurative plot conveying a veiled 


\section{Revista do SELL}

v. $4, n^{\circ} .2$

ISSN: $1983-3873$

implication, also makes use of this process by articulating many symbols whose interpretation allows the reader to understand its masked idea of the birth of man.

The Beast says conceitedly "Fancy thinking the Beast was something you could hunt and kill!" and asks "You knew, didn't you? I'm part of you? Close, close, close! I'm the reason why it's no go? Why things are what they are?" (GOLDING, 1988, p. 147). This embodiment of evil in the form of a putrefying head with flies around it constitutes an effective symbol for "mankind's essential illness" (GOLDING, 1988, p. 89), an understanding Simon inarticulately attempts to communicate.

It is well-known that the poetic narrative erects a closed world and has a time of its own, however, as Tadié (1978) argues, this genre is not supposed to be entirely isolated from the events of History. One of the roles of allegory and its symbols is to recover the present:

Les deux déroulements temporels se coupent. Mais c'est une coupure symbolique, comme les cadavres de la grande guerre, jetés sur les plages de lîle éternelle, et l'allégorie, chargée de la récupération de l'actualité, renforce le temps poétique au lieu de le détruire: elle transforme en image l'instant venu d'ailleurs, le traduit d'un code dans un autre [...]. ${ }^{6}$ (TADIÉ, 1978, p. 94-95).

It is remarkable the similarity of historical context between Tadié's example and the corpse of a parachuted man found by the British boys in the island. The symbol of the Beast as an allegory of the human evilness amalgamates indeed both temporal indications (poetic and contemporary) and allows the reader to trace the origins of this image back to the Second War. It is interesting to reinforce, however, that Lord is not tied historically to such bellicose era, which can only be inferred in the narrative.

If the boys were sent by their parents to a distant place, far away from this war for security purposes, the warlike background serves only as initial propulsion to trigger the main course of events, i.e. the uncovering of the atemporal human vileness, the major element in the plot.

The symbol of decomposing and mutilated bodies, evoked by the figure of the parachuted man, is a representative image standing for the corruptible nature of men. This symbol is also found in another creature in the narrative: in the putrefying pig head of the

\footnotetext{
${ }^{6}$ The two temporal sequences split. But it is a symbolic division, such as the bodies of the Great War, cast on the beaches of the eternal island; and allegory, in charge of recovering the present, reinforces the poetic time instead of destroying it: it turns into image the instant come from elsewhere and translates this code into another [...] (TADIÉ, 1978, p. 94-95). (own translation).
} 


\section{Revista do SELL}

v. $4, n^{\circ} .2$

ISSN: $1983-3873$

beast. It is interesting to notice that the pig is actually a sow, killed when she was "sunk in deep maternal bliss" with her belly "fringed with a row of piglets" (GOLDING, 1988, p. 137).

Firstly, the killing of the only female being in the island could represent symbolically the mistreatment and violence towards women. Our interpretation of the female role in this lyrical novel diverges from Paula Roy's (2010, p. 84), who identifies "a whiff of misogyny or at least a suspicion that what women represent has little impact, finally, on culture or civilization". Also according to Roy (2010, p. 84), Golding "concludes that the female is unsuccessful because she is too weak, flawed, flesh-bound to overcome the ingenuity, craftiness, and sheer brutality of male violence."

We consider that Lord of the flies, however, does not provide the necessary information that would allow the readers to infer these conceptions because of the absence of moralizing judgment. We are presented the development of a plot to a more destructive situation in which the unbiased narrator refrains from expressing moral opinions, a modern aesthetic framework that leaves the novel open to different interpretations without validating overtly any hypothesis.

It would be relevant to discuss then if the narrator's choice for illustrating basically Ralph's point of view would constitute a definite tendency to advocate for a more civilized society. Since the narrator reveals the unexpressed thoughts of other characters, constituting several breaches in Ralph's possible pattern of focalization, and does not point undoubtedly to right or wrong moral attitudes, we are lead to regard Lord as an open narrative which allows various conceivable inferences but does not validate a main philosophical perspective such as feminism, misogyny or machismo.

Attempting to read the narrative in an unbiased way, we see that a male dominated group killed a sow - which could be an analogous glimpse to Piggy's future - and its mortal remains were metamorphosed later into a male figure, the lord of the flies. The possibility of reading morally these signs as either misogynistic or, inversely, supportive of a more female posture in civilization, escapes the quintessential configuration of the narrative techniques in Lord. As a whole, the concrete image of the Beast, on which concentrates such conceptions, concatenates thus the abstract ideas of female/male, aggression/defense, defeat/victory, and universal time/historical time, reinforcing the dialectical courses of the lyrical novel.

Another powerful symbol is the conch, a civilizing object which initially is handled in order to maintain a governable situation in the island based on the regulation of the boys' 


\section{Revista do SELL}

v. $4, n^{\circ} .2$

ISSN: $1983-3873$

speeches. Its mesmerizing aspect was almost solely responsible for the election of Ralph as their chief: "But there was a stillness about Ralph as he sat that marked him out: there was his size, and attractive appearance; and most obscurely, yet most powerfully, there was the conch." (GOLDING, 1988, p. 21).

In his article Power and Authority: An Interpretation of Golding's "Lord of the Flies", David Spitz (1970, p. 26) affirms that, although Ralph discovered the conch, it was Piggy who understood its "significance as a symbol of legitimacy, an instrument of reason and order". However, little by little, as the boys neglect the vestiges of their cultural conducts and instinct emerges as a ruling authority, the conch is inevitably discarded.

Accordingly, the concluding change into savagery is marked by the destruction of both Piggy and the conch: "The rock struck Piggy a glancing blow from chin to knee; the conch exploded into a thousand white fragments and ceased to exist." (GOLDING, 1988, p. 284). In this lyrical fiction, Golding employs the symbol of the conch to deal with what is deficient or on the brink of extinction: rules, governmental actions, respect, agreement, and sensibility.

Similarly, Piggy's glasses symbolize knowledge and his ability to analyze and understand their unpredicted situation. When Piggy is deprived of his spectacles, he is utterly dependent on assistance to walk and on oral description to realize what is going on around him, an individual condition that possibly mirrors the marooned boys collectively destitute of the support of an advanced society. Spitz provides further connotations about the glasses:

Piggy brought his spectacles, an artificial aid provided by the civil society in which he had lived; and so conditioned had he been by that society that with those spectacles he saw precisely those democratic and middle-class values that that society esteemed, he appealed repeatedly to science and to what grown-ups would think. (SPITZ, 1970, p. 30).

Both symbols, the conch and the spectacles, become gradually destitute of their civilizable power and, in this sense, represent a series of things that are perishing. The brutal actions of the boys and their speeches are bonded inextricably to the destruction of these symbols, revealing a connection between form and content highly valued in the lyrical fiction.

Besides the individual benefit generated by Piggy's glasses and their implicit civilizing influence, the narrative reinforces, through the speech of the characters, an 


\section{Revista do SELL}

v. $4, n^{\circ} .2$

ISSN: $1983-3873$

explicit one: "His specs - use them as burning glasses!" (GOLDING, 1988, p. 40). Referring implicitly to the myth of Prometheus, already mentioned in this paper, Lord will focus primarily on the ambiguity of the Titan's gift: the kids are granted the fire, but they are supposed to labor to keep it going.

Furthermore, this symbol undergoes another type of transformation. At a first stage, the bonfire is beneficially seen as their only way out of the island: "There's another thing. We can help them to find us. If a ship comes near the island they may not notice us. So we must make smoke on top of the mountain." (GOLDING, 1988, p. 37). The group, still undivided, struggles to keep it burning, though some kids are more disciplined than others.

As time and civility go by, the fire becomes a threat to Ralph, who is being hunt down: "Then Ralph was running beneath trees, with the grumble of the forest explained. They had smoked him out and set the island on fire." (GOLDING, 1988, p. 202). By now, the bonfire is converted into a symbol of destruction and murder.

In a third stage, the arrival of the naval officer interrupts their hunt and unintentionally saves Ralph's life: "We saw your smoke. What have you been doing? Having a war or something?" (GOLDING, 1988, p. 206). The symbol of the fire ironically reacquires its first meaning of rescue and return to civilization, granting the novel a cyclical framework. About the variety of connotations provided by the symbols, Tadié explains that:

On voit alors que le symbole, lorsqu'il apparaît dans une phrase, dans une scène du récit, fournit une pluralité de significations à cette phrase, à cette scène, mais aussi à d'autres scènes en écho, puis à tout le récit, aux autres récits de l'auteur, et finalement au monde extra-littéraire lui-même, sans pour autant s'assembler avec les autres symboles du même texte selon l'ordonnance cohérente du discours scientifique: dans le récit poétique, tous les symboles fonctionnent en même temps, et le même symbole, à des moments différents, fonctionne différemment. ${ }^{7}$ (TADIE, 1978, p. 166-7).

Focusing on Lord, we see that both Piggy's glasses and the bonfire bring together opposite ideas: the ease and promptness of making fire vs. the labor involved in the action and rescue vs. annihilation. Considering the inevitable implications of temporal sequences of cause and effect pertaining to dialectical circumstances, it is possible to identify that attempt, conceived by Freedman (1963, p. 113-4), "distinctive of lyrical fiction, to convert

\footnotetext{
${ }^{7}$ The symbol, when used in a sentence, in a scene of the story, provides a plurality of meanings to this phrase, to this scene, but also to other scenes, to the whole story, to other narratives of the author and finally to the extra-literary world itself, without bringing together other symbols of the same text in accord with the consistent order of scientific discourse: in the poetic narrative, all the symbols work at the same time, and the same symbol at different times works differently. (TADIE, 1978, p. 166-7). (own translation).
} 


\section{Revista do SELL}

v. $4, n^{\circ} .2$

ISSN: $1983-3873$

the linear progression of the novel into one or several single situations portrayed as a pattern of images."

Finally, the end of the lyrical novel reveals its second cyclical configuration: the rescue of the boys and their future reintegration into society. Ralph's emotional burst indicates his sudden realization that they will only return to a similar communal structure governed by a frail civility: "And in the middle of them, with filthy body, matted hair, and unwiped nose, Ralph wept for the end of innocence, the darkness of man's heart, and the fall through the air of the true, wise friend called Piggy." (GOLDING, 1988, p. 229).

In this sense, Ralph seems to unmask men's elemental core by "understanding that man produces evil as a bee produces honey" (GOLDING, 1965, p. 85) and, since Lord is an allegorical narrative mirroring contemporaneous, adult society, their homecoming is rendered essentially insignificant.

As Freedman (1963, p. 72-73) states, the protagonist in the lyrical novel is selfreflective "because his behavior in a world of simulated time and place actually mirrors his own psyche" and his experiences are defined by occurrences that represent the external world. This artistic device, we believe, induces the reader to perceive himself, in a logical process, as one of the participants of this misfortune.

\section{Conclusion}

In this study we demonstrated how Lord of the flies relates more coherently to the genre of lyrical novel or poetic narrative based mainly on the works Le récit poétique, by Jean-Yves Tadié (1978), and The lyrical novel, by Ralph Freedman (1963).

Literary space is consolidated into the image of a paradisiacal island, the navel of the fictional world, and exposes a Manichaean partition in harmony with the ideas of instinct and civilization. Time, homologous with space, is immobile, suspended in the concentric moment of the schoolboys' isolation and focus seasonal and light/darkness transitions. Myth, in explaining how a given reality happened for the first time, portrays in Lord the birth of man, vile in nature. Allegory points to secondary meanings underlying the symbols of mutilated bodies, denoting the corruptible nature of men, the conch, representing civilization, Piggy's glasses, standing for knowledge, and the bonfire, denoting development, destruction and rescue.

Therefore, the analysis of such concepts may contribute to a fresh reading of this children's narrative, which clearly diverges from the traditional, realist novel. 


\section{References}

FREEDMAN, Ralph. The lyrical novel: studies in Hermann Hesse, André Gide, and Virginia Woolf. New Jersey: Princeton University Press, 1963.

GOLDING, William. The hot gates and other occasional pieces. New York, NY: Pocket Books, 1965.

Lord of the flies. New York, NY: Penguin Group, 1988.

KRUGER, Arnold. A new look at the character of Simon. In: BLOOM, Harold. (Ed.). Bloom's guides: Lord of the flies. New York: Infobase Publishing, 2010.

ROY, Paula. On the absence of the female in Lord of the flies. In: BLOOM, Harold. (Ed.). Bloom's guides: Lord of the flies. New York: Infobase Publishing, 2010.

SPITZ, David. Power and authority: an interpretation of Golding's "Lord of the Flies". The Antioch Review, Greene, v. 30, n. 1, p. 21-33, 1970. Available in: <http://www.jstor.org/stable/4637248>. Accessed in: 28 aug 2012.

TADIÉ, Jean-Yves. Le récit poétique. Paris: Presses Universitaires de France, 1978. TODOROV, Tzvetan. Genres in Discourse. Cambridge: Cambridge University Press, 1990. 